Bangladesh J. Zool. 49 (2): 189-203, 2021

ISSN: 0304-9027

eISSN: $2408-8455$

\title{
HEAVY METAL CONCENTRATIONS AND HUMAN HEALTH RISK ASSESSMENT OF SELECTED WILD AND CULTURED FISHES OF BANGLADESH
}

\author{
Ami Akter ${ }^{1}$, Anowar Hosen ${ }^{2}$, Md. Amjad Hossain ${ }^{3}$ \\ Farzana Khalil ${ }^{4}$ and Tonima Mustafa ${ }^{1 *}$ \\ Department of Zoology, Jagannath University, Dhaka-1100, Bangladesh
}

\begin{abstract}
This study was conducted to estimate the concentration of selected heavy metals such as chromium $(\mathrm{Cr})$, manganese $(\mathrm{Mn})$, cobalt $(\mathrm{Co})$, nickel $(\mathrm{Ni})$, copper $(\mathrm{Cu})$, zinc $(\mathrm{Zn})$, cadmium $(\mathrm{Cd})$, and lead $(\mathrm{Pb})$ as well as the possible risk to consumer health from the flesh of three wild and cultured fishes (Labeo rohita, Mystus cavasius, and Heteropneustes fossilis) collected from the Meghna river, Narayangonj and Rajoir fish farm, Madaripur district respectively. Heavy metal concentrations were determined using Atomic Absorption Spectrometric method. The average concentration of heavy metals were found in the wild fish samples in the range as $\mathrm{Cr}$ (0.295-1.647), $\mathrm{Mn}$ (0.900-1.294), Ni (0.063-0.198), Cu (0.1790.529), $\mathrm{Zn}$ (5.487-8.343), $\mathrm{Cd}$ (0.004-0.009) and $\mathrm{Pb}(0.193-0.290) \mathrm{mg} / \mathrm{kg}$ dry weight while in the cultured fish samples in the range as $\mathrm{Cr}(0.043-0.315), \mathrm{Mn}$ (0.975-2.36), Co (BDL), Ni (0.005-0.095), Cu (0.238-0.978), Zn (5.487-8.305), Cd (0.004-0.009), and $\mathrm{Pb}(0.238-0.286) \mathrm{mg} / \mathrm{kg}$ dry weight respectively. The hierarchy of mean concentration of heavy metals in wild fishes was $\mathrm{Zn}>\mathrm{Mn}>\mathrm{Cu}>\mathrm{Pb}>\mathrm{Cr}>\mathrm{Ni}$ $>\mathrm{Cd}$ and in the cultured fishes, the order was found $\mathrm{Zn}>\mathrm{Mn}>\mathrm{Cr}>\mathrm{Pb}>\mathrm{Cu}>\mathrm{Ni}>$ Cd. The present study showed that the wild fish accumulated higher concentration of heavy metals in their muscles than the cultured fish. The analyzed $\mathrm{Ni}, \mathrm{Cu}, \mathrm{Zn}, \mathrm{Cd}$, and $\mathrm{Pb}$ were below the allowable level specified by international agencies (FAO, WHO, EU, CE, USEP). In order to assess the human health risk, the Target Hazard Quotient (THQ), Hazard Index (HI), and Target carcinogenic Risk (TR) were calculated. The TR values suggested that the fishes posed low to moderate carcinogenic risk from $\mathrm{Cr}, \mathrm{Ni}$ and $\mathrm{Cd}$. Consequently, continuous and excessive consumption of these fish species over a lifetime will increase the possibility of causing cancer.
\end{abstract}

Key words: Heavy metals, fish, Atomic Absorption Spectrometry, health risk

\section{INTRODUCTION}

Bangladesh is regarded as one of the foremost suitable areas for harvesting

*Author for corresponding: <tonimamustafa@yahoo.com>, ${ }^{2}$ Basic Facilities and Sample processing Laboratory, Center for Advanced Research in Sciences (CARS), University of Dhaka, Dhaka-1000, Bangladesh, ${ }^{3}$ Institute of Leather Engineering and Technology, University of Dhaka, Dhaka-1000, Bangladesh, ${ }^{4}$ American International University Bangladesh, Dhaka, Bangladesh

(C2021 Zoological Society of Bangladesh DOI: : https://doi.org/10.3329/bjz.v49i2.56257 
fish and other aquatic life in the world. It has the world's largest submerged wetland and Asia's third largest aquatic biodiversity after China and India (Shamsuzzaman et al. 2017). The inland water resources of Bangladesh provide great potential for the expansion and development of freshwater fisheries and aquaculture (Hossain 2014). River pollution has been a serious issue in Bangladesh because of increasing industrialization, which has resulted in a rise in the usage of chemicals as raw material. In addition, anthropogenic human activities are increasing the availability of heavy metals in water reservoirs at an alarming rate, especially lakes, canals, rivers and aquatic organisms, which has become a global problem (Malik et al. 2010). Animal wastes like livestock, poultry, and cattle manures are utilized as food in aquaculture ponds and are normally provided to fish in the form of solids or semisolids. The manures produced by animals as a result of these diets include higher levels of copper, arsenic, and zinc and if fed to fish in a pond regularly, can result in a considerable accumulation of these metals over time in the sediment (Basta et al. 2005). In developed and developing countries like Bangladesh, heavy metal pollution is increasingly contaminating soil, sediment, vegetables, water and fish, which has become a worldwide concern (Ahmad et al. 2010 and Islam et al. 2014). Heavy metals cause a serious threat to the aquatic environment due to their toxicity, accumulation, and magnification in aquatic organisms (Roy 2010). Heavy metals are a concern not just to public water supplies, but also to human health when consumed in aquatic products, especially fish (Terra et al. 2008).

Fish has been known as a good accumulator of organic and inorganic pollutants (Gado et al. 2003). Human uptakes the pollutants through consumption of fish. Heavy metal toxicity in the human body can result in cardiovascular illness, liver damage, renal failure, and even death. (Castro et al. 2008 and Rahman et al. 2012). Furthermore, chronic lead exposure can cause sickness, mental impairment, and even death (Al-Busaidi et al. 2011). Cadmium damages the kidneys and causes chronic toxicity symptoms such as decreased renal function, decreased reproductive capacity, hypertension, tumors, and hepatic dysfunction (Al-Busaidi et al. 2011, Luckey and Venugopal 1977 and Rahman and Islam 2010). Other metals, such as chromium, zinc, and copper, can induce nephritis, anuria, and severe kidney lesions (Luckey and Venugopal 1977 and Rahman and Islam 2009). Heavy metal contamination has a detrimental impact on the ecological balance of the adoptive environment and the diversity of aquatic organisms (Vosyliene and Jankaite 2006). Therefore, the problem of heavy metal pollution in fish has drawn global attention.

As fish can metabolize xenobiotic and bio-accumulate pollutants directly from polluted water and sediment by diffusion through gill and skin, or they 
may ingest metals with their food, they provide a suitable model for assessing aquatic toxicity and wastewater quality (Al-Sabti et al. 1995, Minissi et al. 1996 and Frank et al. 1999). Fish are often used as biological indicators because they play multiple roles in the nutrient network, bio-accumulate toxic substances, and respond to low concentrations of pollutants (Klobucar et al. 2010). Furthermore, fish are known for their ability to accumulate heavy metals in their muscles while muscle is the main part of the absorption of metals and, since fish is an important part of the human diet. But it must be carefully examined to ensure that excessive levels of heavy metals are not being transferred to the human through fish consumption (Mahboob et al. 2014). The present study was aimed to analyze the heavy metal concentrations in three commonly consumed fish species of wild and cultured type and to estimate the health risk to human through dietary consumption.

\section{MATERIAL AND METHODS}

Sample collection: The three commonly consumed fish species such as Rui (Labeo rohita), Gulsha (Mystus cavasius) and Shing (Heteropnuestes fossilis) of both wild and cultured type were studied to determine the heavy metal concentrations. Wild fish samples were collected directly from the fisherman of the Meghna River at Boidyer Bazar, Narayanganj District and cultured fish samples were collected from a culture pond of Rajoir fish farm, Rajoir upazila, Madaripur district, in November 2019 (Fig. 1). In case of Rui fish, ten fish samples were collected and incase of Gulsha and Shing, around three Kilogram fishes (55 Gulsha individuals and 45 Shing individuals) were collected. The samples were transported immediately to the fisheries laboratory of the department of Zoology, Jagannath University into a chill-box. Collected samples were identified by using the morphological characteristics, following Shafi and Quddus (1982), Rahman (2005) and Fish base (2014), and then stored in freezer at $-20{ }^{\circ} \mathrm{C}$ in jip-locked plastic bags with proper labeling.

Sample preparation: The samples were taken out from the freezer and thaw at room temperature. The muscles of fishes were taken with the help of steam cleaned stainless steel knife and washed with distilled water. The cleaned fish muscles were homogenized by a blender. Three replicates of each grinded fish sample were analyzed. The determination of moisture and ash contents and digestion were carried out in the Basic Facilities and Sample Processing Laboratory of Centre for Advanced Research in Science (CARS), University of Dhaka, Bangladesh. The analysis of eight different heavy metals namely chromium $(\mathrm{Cr})$, manganese $(\mathrm{Mn})$, cobalt $(\mathrm{Co})$, nickel $(\mathrm{Ni})$, copper $(\mathrm{Cu})$, zinc $(\mathrm{Zn})$, 
cadmium $(\mathrm{Cd})$, and lead $(\mathrm{Pb})$ was carried out in BCSIR (Bangladesh Council of Scientific and Industrial Research), Dhaka.

\section{Study Area}
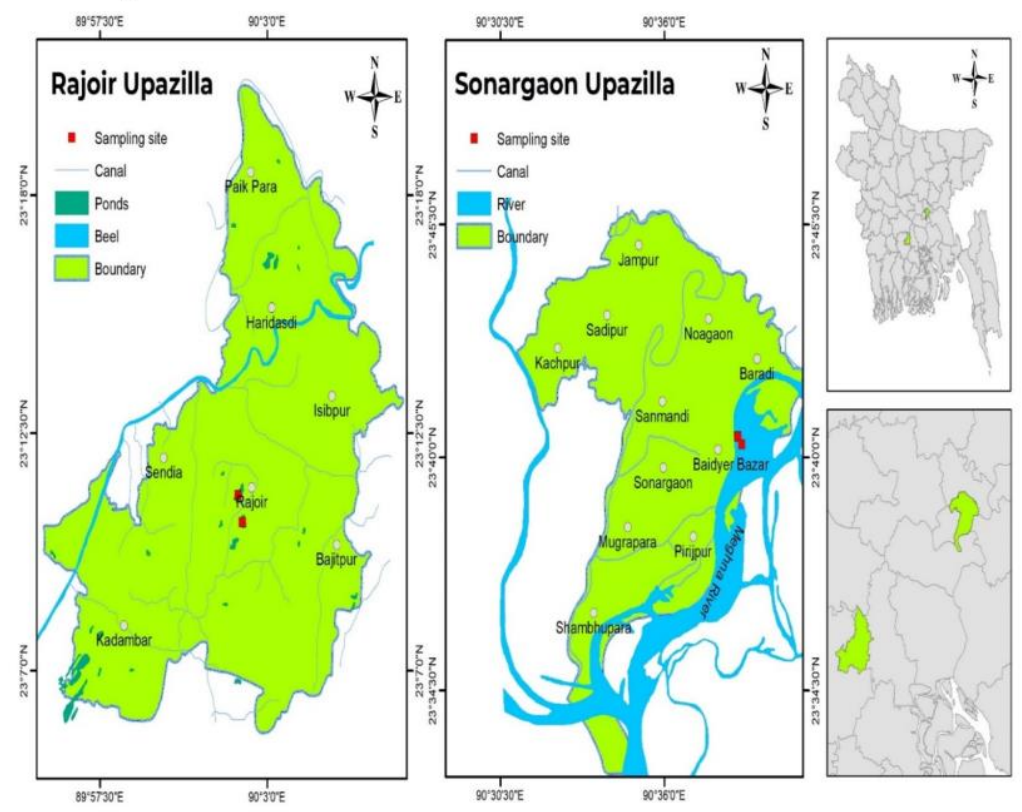

Fig 1. Location Map of study areas (Culture Pond of Rajoir upazilla, Madaripur and Meghna river of Boidyer Bazar, Sonargaon Upazila, Narayanganj)

Determination of moisture content: The weight of moisture free dried empty crucibles was taken, then $10 \mathrm{~g}$ blended fish sample were added in each crucible. The crucibles with samples were placed in an oven at $105{ }^{\circ} \mathrm{C}$ for 6 hours and then transferred into desiccators. The repeated weight was taken till constant weight was obtained and recorded.

Determination of ash content: The crucible containing samples were placed in muffle furnace covering with a watch glass remaining a slight gap at $150{ }^{\circ} \mathrm{C}$ for $1 \mathrm{~h}$ and then the temperature of the furnace was raised to $200{ }^{\circ} \mathrm{C}, 300{ }^{\circ} \mathrm{C}$ and $400{ }^{\circ} \mathrm{C}$ gradually to avoid the loss of sample. The temperature was raised to $600{ }^{\circ} \mathrm{C}$, keeping for 8 hours to obtain ash that is white and free from carbon. Afterwards crucibles were transferred to the desiccators, weighting were repeated till constant weight was obtained and recorded.

Digestion of fish samples: For digestion, $0.2 \mathrm{~g}$ dried sample was taken in a beaker and $5 \mathrm{~mL}$ of conc. $\mathrm{HNO}_{3}$ was added to the beaker. Then the samples were 
put on hot plate at $60{ }^{\circ} \mathrm{C}$ for digestion under fume hood. When the concentration drops, add $2 \mathrm{~mL} \mathrm{H}_{2} \mathrm{O}_{2}$ to each sample. Finally, place the mixture on a hot plate at $100^{\circ} \mathrm{C}$ under a fume hood covering with a watch glass until it become transparent. The digests were allowed to cool and filtered with filter paper, then transferred to a different $50 \mathrm{~mL}$ volumetric flask and filled to the 25 $\mathrm{mL}$ mark with deionized water to obtain the final volume as a stock solution and kept ready for heavy metal analysis through Atomic Absorption Spectrometry (AAS).

Standards: Standard solutions of selected eight heavy metals such as $\mathrm{Cr}$, $\mathrm{Mn}, \mathrm{Co}, \mathrm{Ni}, \mathrm{Cu}, \mathrm{Zn}, \mathrm{Cd}$, and $\mathrm{Pb}$ were provided by Fluka Analytical, SigmaAldrich (Germany). A calibration curve was prepared for all elements by running different concentrations of standard solutions prepared from certified reference materials (CRM) obtained from Fluka Analytical, Sigma-Aldrich. The standards were prepared from the individual $1000 \mathrm{mg} / \mathrm{L}$ standards (Merck) supplied in $0.1 \mathrm{~N}$ HNO3. A series of working standards were prepared from these standard stock solutions.

Analysis of heavy metal by AAS: Eight heavy metal i.e. $\mathrm{Cr}, \mathrm{Mn}, \mathrm{Co}, \mathrm{Ni}, \mathrm{Cu}$, $\mathrm{Zn}, \mathrm{Cd}, \mathrm{Pb}$ were determined by AAS using Zeeman Atomic Absorption Spectrophotometer (GTA 120-AA240Z with PSD 120 auto sampler, Varian, Australia). Measurements were carried out using standard hollow cathode lamps for $\mathrm{Cr}, \mathrm{Mn}, \mathrm{Co}, \mathrm{Ni}, \mathrm{Cu}, \mathrm{Zn}, \mathrm{Cd}$, and $\mathrm{Pb}$. The standard operating conditions for the analysis of heavy metals using AAS used in the experiments are given in Table-1. The results were shown as $\mathrm{mg} / \mathrm{kg}$ or $\mathrm{ppm}$ of dry weight. The glassware and containers used in the study were cleaned thoroughly then rinsed with double distilled water for 3-4 times and dried in air prior to use.

Table 1. Standard operating conditions for metal analysis using AAS

\begin{tabular}{ccccc}
\hline Element & $\begin{array}{c}\text { Lamp current } \\
\text { (mA) }\end{array}$ & $\begin{array}{c}\text { Wavelength } \\
\text { (nm) }\end{array}$ & Flame & Slit setting (nm) \\
\hline $\mathrm{Zn}$ & 5.0 & 213.9 & Air-acetylene & 1.0 \\
$\mathrm{Cr}$ & 7.0 & 357.9 & & 0.2 \\
$\mathrm{~Pb}$ & 10.0 & 279.5 & & 1.0 \\
$\mathrm{Cu}$ & 4.0 & 324.8 & 0.5 \\
$\mathrm{Mn}$ & 5.0 & 217.0 & 0.2 \\
$\mathrm{Ni}$ & 10.0 & 232.0 & 0.2 \\
$\mathrm{Cd}$ & 4.0 & 228.8 & 0.5 \\
\hline
\end{tabular}

Health Risk assessment: The values of heavy metal concentration were used to calculate the estimated target hazard quotients (THQ), hazard index (HI), and target cancer risk (TR) of individuals. 
Target Hazard Quotient: The Target Hazard Quotient (THQ) is a measure of the level of non-cancer risk associated with exposure to contaminants. THQ is evaluated using the US Environmental Protection Agency Risk-Based concentration Table-III to estimate the risk to human health from the consumption of metal-contaminated fish (US EPA 2011). The formula used for calculating the THQ is as follows:

$$
\text { THQ }=\frac{\text { EF } \times \text { ED } \times \text { FIR } \times \text { CF } \times \text { CM }}{\text { WAB } \times \text { ATn } \times \text { RfD }} \times 10^{-3}
$$

where THQ is the target hazard quotient, EF is the exposure frequency (365 days/year), ED is the exposure duration (30 years for non-cancer risk as used by USEPA 2011), FIR is the fish ingestion rate (49.5 g/person/day; BBS 2011), $\mathrm{Cf}$ is the conversion factor $(00.208)$ to convert fresh weight $(\mathrm{Fw})$ to dry weight (Dw) considering $79 \%$ of moisture content in fish, $\mathrm{CM}$ is the heavy metal concentration in fish (mg/ $\mathrm{kg} \mathrm{d} . \mathrm{w}), \mathrm{WAB}$ is the average body weight (bw) $(70 \mathrm{~kg})$, ATn is the average exposure time for non-carcinogens $(\mathrm{EF} \times \mathrm{ED}$ ) (365 days/year for 30 years (i.e., ATn=10,950 days) as used in characterizing non-cancer risk (USEPA 2011), and RfD is the reference dose for metals where, $\mathrm{Cr}=0.003, \mathrm{Mn}$ $=0.14, \mathrm{Co}=0.0003, \mathrm{Ni}=0.14 \mathrm{Cu}=0.03, \mathrm{Zn}=0.3, \mathrm{Cd}=0.001$ and $\mathrm{Pb}=0.2$ (USEPA 2011, 2012).

Hazard index: To assess the overall potential health risks of more than one metal, the THQ of each metal is added together called the Hazard Index (HI). $\mathrm{HI}$ can be calculated by summing the target risk ratio of each metal (USEPA 2011).

Here, HI =THQ (Zn) + THQ (Pb) + THQ (Mn) + THQ (Ni) + THQ (Cu) + THQ (Cr) + THQ (Cd)

Target cancer risk: Target cancer risk (TR) is used to indicate cancer risk. The US Environmental Protection Agency's Zone III Hazard-Based Concentration Table (USEPA 2011) also provides a method for estimating TR. The model to calculate TR is the following:

$$
\mathrm{TR}=\frac{\mathrm{EF} \times \mathrm{ED} \times \mathrm{FIR} \times \mathrm{CF} \times \mathrm{CM} \times \mathrm{CPSO}}{\mathrm{WAB} \times \mathrm{ATC}} \times 10^{-3}
$$

Where TR is the target cancer risk, CPSo is the carcinogenic potency slope, oral ( $\mathrm{mg} / \mathrm{kg}$ bw/day), and ATc is the averaging time, carcinogens (365 days/year for 70 years as used by USEPA 2011). Since CPSo values of $\mathrm{Cr}(0.5)$, Ni (1.7) (USEPA, 2011), Cd (0.6) and $\mathrm{Pb}$ (0.009) (Alam et. al. 2015 and Oehha 2011) were only known. Therefore, the TR value of the intake of these metals was calculated.

\section{RESULTS AND DISCUSSION}

Moisture content: The moisture content in the studies fishes ranged between $74.61 \%$ (cultured $H$. fossilis) to $84.64 \%$ (wild $H$. fossilis) (Table 2). The 


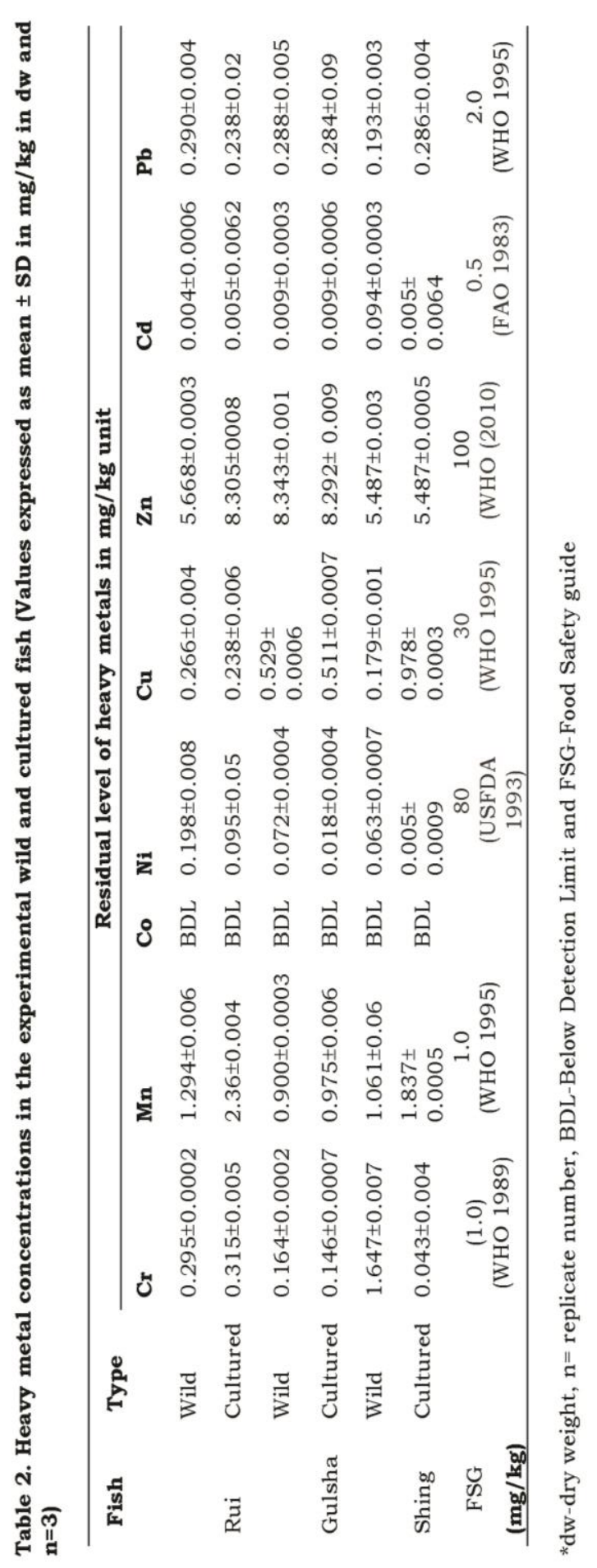


mean concentrations of moisture content were analyzed in the sequences of $78.68 \%$ (M. cavasius) $<83.09 \%$ ( $H$. fossilis) $<84.64 \%$ (L. rohita) in the wild samples and $74.61 \%$ (H. fossilis) $<76.83 \%$ (L. rohita) $<80.28^{\circ} \%$ (M. cavasius) in cultured samples respectively.

Ash content: The ash content in the experimental fishes ranged between $1.28 \%$ (cultured L. rohita) to $2.76 \%$ (cultured M. cavasius) (Table 2). The mean concentrations of ash contents were found in the ranking order of $1.67 \%(M$. cavasius) $<1.769 \%$ ( $H$. fossilis) $<1.92 \%$ (L. rohita) in wild fish and $1.28 \%$ ( $L$. rohita $)<1.67 \%$ ( $H$. fossilis $)<2.76^{\circ} \%$ ( $M$. cavasius) in cultured fish respectively. The moisture and ash contents varied considerably might be due to differences in species, trophic position and habitat etc.

Heavy metals: The concentrations of eight heavy metals such as $\mathrm{Cr}, \mathrm{Mn}, \mathrm{Co}$, $\mathrm{Ni}, \mathrm{Cu}, \mathrm{Zn}, \mathrm{Cd}$, and $\mathrm{Pb}$ in the wild and cultured fish species were observed (Table 2).

Chromium (Cr): The mean concentration of $\mathrm{Cr}$ in the fishes was in the range of 0.043 (cultured $H$. fossilis) to 1.647 (wild $H$. fossilis) $\mathrm{mg} / \mathrm{kg}$ dry-wt basis. It was analyzed in the order of 0.164 (M. cavasius) $<1.647$ (H. fossilis) $<0.295$ (L. rohita) $\mathrm{mg} / \mathrm{kg} \mathrm{dw}$ in wild fishes and 0.043 (H. fossilis) $<0.146$ (M. cavasius) < 0.315 (L. rohita) 0.164 (M. cavasius) $\mathrm{mg} / \mathrm{kg} \mathrm{dw}$ in cultured fishes. The concentration in wild $H$. fossilis was above the recommended maximum permissible limit $1.0 \mathrm{mg} / \mathrm{kg}$ (WHO, 1989).

Manganese (Mn): The range of the average concentration of $\mathrm{Mn}$ in fishes was 0.900 (wild $M$. cavasius) to 2.36 (cultured L. rohita) $\mathrm{mg} / \mathrm{kg} \mathrm{dw}$. While the ascending orders of this content are as follows: 0.900 (M. cavasius) $<1.061(\mathrm{H}$. fossilis) < 1.294 (L. rohita) $\mathrm{mg} / \mathrm{kg} \mathrm{dw}$ in wild fishes and 0.975 (M. cavasius) < 1.837 (H. fossilis) < 2.36 (L. rohita) $\mathrm{mg} / \mathrm{kg} \mathrm{dw}$ in cultured fishes. The $\mathrm{Mn}$ concentrations in four samples out of six, namely wild and cultured L.rohita and $H$. fossilis were higher than the recommended maximum permissible limit 1.0 $\mathrm{mg} / \mathrm{kg}$ (WHO, 1995).

Cobalt (Co): Co was analyzed as below detected limit in all the six samples.

Nickel (Ni): Ni content varied between 0.018 (cultured M. cavasius) to 0.198 (wild L. rohita) $\mathrm{mg} / \mathrm{kg} \mathrm{dw}$. This metal was distributed according to the chronologies: 0.063 (H. fossilis) < 0.072 (M. cavasius) $<0.198$ (L. rohita) $\mathrm{mg} / \mathrm{kg}$ $\mathrm{dw}$ in wild fishes and 0.004 (H. fossilis) $<0.018$ (M. cavasius) < 0.095 (L. rohita) $\mathrm{mg} / \mathrm{kg} \mathrm{dw}$ in cultured fishes.

Copper $(\mathrm{Cu})$ : Copper was detected at mean concentrations between 0.179 (wild $H$. fossilis) to 0.978 (cultured $H$. fossilis) $\mathrm{mg} / \mathrm{kg} \mathrm{dw}$. The metal was distributed as 0.179 (H. fossilis) $<0.266$ (L. rohita) $<0.529$ (M. cavasius) $\mathrm{mg} / \mathrm{kg}$ 
$\mathrm{dw}$ in the wild fishes and 0.238 (L. rohita) $<0.511$ (M. cavasius) $<0.978$ ( $H$. fossilis) $\mathrm{mg} / \mathrm{kg} \mathrm{dw}$ in cultured fishes.

Zinc $(Z n)$ : The mean concentration of $Z n$ was in the range of 5.487 (wild $H$. fossilis) to 8.343 (wild $M$. cavasius) $\mathrm{mg} / \mathrm{kg} \mathrm{dw}$. It was distributed according to the chronologies: 5.487 (H. fossilis) $<5.668$ (L. rohita) $<8.292$ (M. cavasius) and 5.487 (H. fossilis) $<8.291$ (M. cavasius) $<8.305$ (L. rohita) $\mathrm{mg} / \mathrm{kg} \mathrm{dw}$ in wild and cultured fishes respectively.

Cadmium (Cd): The highest $\mathrm{Cd}$ concentration was found in wild $H$. fossilis $(0.094 \mathrm{mg} / \mathrm{kg})$ and the lowest was in wild L. rohita $(0.004 \mathrm{mg} / \mathrm{kg})$. It was analyzed in the order of 0.004 (M. cavasius) $<0.009$ (L. rohita) $<0.094$ ( $H$. fossilis) $\mathrm{mg} / \mathrm{kg} \mathrm{dw}$ in wild fishes and 0.004 (H. fossilis) $<0.005$ (L. rohita) $<0.009$ (M. cavasius) $\mathrm{mg} / \mathrm{kg} \mathrm{dw}$ in the cultured fishes.

Lead $(P b)$ : Lead was varied between 0.193 (wild $H$. fossilis) to 0.290 (wild $L$. rohita) $\mathrm{mg} / \mathrm{kg}$ dry-wt. This metal was detected in the orders of 0.193 ( $\mathrm{H}$. fossilis) $<0.288$ ( $M$. cavasius) $<0.290$ (L. rohita) and 0.238 (L. rohita) $<0.284$ ( $M$. cavasius) $<0.286$ ( $H$. fossilis) $\mathrm{mg} / \mathrm{kg} \mathrm{dw}$ in wild and cultured fishes respectively.

The analysis showed that the heavy metals detected in fishes varied considerably among different species and also the same species of different habitats. The variation might be due to the fact that accumulation of heavy metals in the fish muscles depends on several factors such as metal concentration, ways of metal uptake, trophic position of fish, physico-chemical condition of the surrounding environment and intrinsic factors (fish age, trophic position, metabolic rate etc.) (Jezierska and Witeska 2006). The result from the comparison with other reported values showed that the degree of contamination in fishes of the study area was found lower from Buriganga and Turag river (Baki et al. 2019 and Ahmad et al. 2016), Bay of Bengal (Jothi et al. 2018) of the country while higher from the Dhaleshwari river (Ahsan et al. 2018). The heavy metal concentrations in fishes from Kelanta river, Malaysia (Hashim et al. 2014), Bay of Bengal, India (Mitra et al. 2011), river Niger, Nigeria (Ujah et al. 2017) were also higher than the present study.

Comparison between wild and cultured fish sample: The wild M. cavasius fish contained higher amount of all detected heavy metals expect Mn than the cultured $M$. cavasius. Wild $H$. fossilis contained higher amount of four heavy metals $(\mathrm{Cr}, \mathrm{Ni}, \mathrm{Zn}$ and $\mathrm{Cd})$ than the cultured one. The wild L. rohita contained higher amount of three metals ( $\mathrm{Ni}, \mathrm{Cu}$ and $\mathrm{Pb}$ ) than cultured sample. The result revealed that the wild fishes were comparatively contaminated with higher accumulation of the analysed heavy metals than cultured species, and it may be attributed to the pollution in the water and sediment of Meghna river (Hassan et al. 2015). 
Health risk assessment: Risk assessment for bio-accumulated heavy metals was estimated using target hazard quotient (THQ), hazard index (HI) and target cancer risk (TR). These parameters depend not only on intake amount of contaminant but also deal with exposure frequency and duration, average body weight and oral reference dose (RfD).

THQ: The THQ value has been acknowledged as one of the acceptable parameters for assessing the risk of metals related to contaminated fish consumption (Li et al. 2013). The THQ was used to estimate non-carcinogenic risk, and the acceptable threshold level was set at 1, as suggested by the USEPA (2011). If the THQ value is 1 , it indicates that there is a little or no noncarcinogenic risk for consumers, however, if it exceeds the specified limits, it may have negative consequences for consumers. The THQ values of heavy metals obtained by consuming the muscles of wild and cultured L. rohita, $H$. fossilis, and M. cavasius were showed in Table. 3. THQ values for all individual heavy metals were less than 1 in all three fish species, indicating that ingesting a single heavy metal through the diet of these fish has no non-carcinogenic health risk.

Hazard Index (HI): If the value of HI exceeds 1 indicating the metal is toxic cause health hazard to human ( $\mathrm{Li}$ et al. 2013). The values of $\mathrm{HI}$ in all the samples were below the tolerable limit 1 .

Table 3. Target hazard quotient (THQ) and Hazard index (HI) for different heavy metals and their hazard index (HI) in the experimental wild and cultured fish

\begin{tabular}{lllllll}
\hline & \multicolumn{3}{c}{ Wild fish species } & \multicolumn{3}{c}{ Cultured fish species } \\
\hline Metal & L. rohita & M. cavasius & H. fossilis & L. rohita & M. cavasius & H. fossilis \\
\hline $\mathrm{Cr}$ & 0.002770 & 0.004090 & 0.002690 & 0.001542 & 0.007192 & 0.002690 \\
$\mathrm{Mn}$ & 0.012187 & 0.012103 & 0.008110 & 0.007546 & 0.003117 & 0.012019 \\
$\mathrm{Ni}$ & 0.004138 & 0.002678 & 0.003392 & 0.000100 & 0.000019 & 0.005874 \\
$\mathrm{Cu}$ & 0.001959 & 0.003894 & 0.001317 & 0.001752 & 0.003759 & 0.007135 \\
$\mathrm{Zn}$ & 0.001446 & 0.000799 & 0.000804 & 0.004071 & 0.004065 & 0.002103 \\
$\mathrm{Cd}$ & 0.000208 & 0.000075 & 0.000065 & 0.000691 & 0.001382 & 0.000004 \\
$\mathrm{~Pb}$ & 0.000706 & 0.001382 & 0.01382 & 0.001001 & 0.011934 & 0.000691 \\
\hline $\mathrm{HI}$ & 0.023414 & 0.025021 & 0.030198 & 0.023414 & 0.025021 & 0.030198 \\
\hline
\end{tabular}

*HI=Hazard Index

Target Cancer Risk (TR): According to the New York State Department of Health (USEPA, 1989), the TR category is described as if TR $\leq 10^{-6}=10 w ; 10^{-4}$ to $10^{-3}=$ medium; $10^{-3}$ to $10^{-1}=$ high; $\geq 10^{-1}=$ Very high probability of causing cancer. Like THQ, estimated lifetime cancer risk (TR) is not a specific estimate of expected cancer. Rather, it appears to be the upper limit of the chance that an individual may develop cancer at some point in the consumer's life after 
exposure to the toxicant (NYSDOH 2007). The values of TR for $\mathrm{Cr}, \mathrm{Ni}, \mathrm{Cd}$ and $\mathrm{Pb}$ of the studied fishes were shown in the Table 4 . The both wild and cultured $L$. rohita and $M$. cavasius as well as wild $H$. fossilis fish samples had TR in the order of $10^{-4}$ in terms of $\mathrm{Cr}$ metal. The present study found that total of five fish samples out of six had a moderate carcinogenic risk from $\mathrm{Cr}$ as these fish have carcinogenic slope potency in $10^{-4}$ order. All the six fish samples posed a low cancer risk from $\mathrm{Ni}$ consumption as these fish have TR value in the range of E-5 to E- 6 order. On the other hand, wild $H$. fossilis samples had E- 6 order value for metal $\mathrm{Cd}$ consumption; therefore, this fish had a low carcinogenic risk from $\mathrm{Cd}$ consumption. In addition, none of fish species were in cancer risk in terms of lead consumption as they have TR value E-7 order.

Table 4. TR values for $\mathrm{Cr}, \mathrm{Ni}, \mathrm{Cd}$ and $\mathrm{Pb}$ of the experimental wild and cultured fish samples

\begin{tabular}{ccccccc}
\hline Heavy metal & \multicolumn{3}{c}{ Wild fish species } & \multicolumn{3}{c}{ Cultured fish species } \\
\hline & L. rohita & M. cavasius & H. fossilis & L. rohita & M. cavasius & H. fossilis \\
$\mathrm{Cr}$ & $6.51 \mathrm{E}-04$ & $3.63 \mathrm{E}-04$ & $3.68 \mathrm{E}-04$ & $6.95 \mathrm{E}-04$ & $3.22 \mathrm{E}-04$ & $9.49 \mathrm{E}-05$ \\
$\mathrm{Ni}$ & $4.97 \mathrm{E}-05$ & $1.18 \mathrm{E}-05$ & $1.57 \mathrm{E}-05$ & $2.38 \mathrm{E}-05$ & $4.73 \mathrm{E}-06$ & $1.18 \mathrm{E}-06$ \\
$\mathrm{Cd}$ & $4.23 \mathrm{E}-07$ & $8.29 \mathrm{E}-07$ & $8.26 \mathrm{E}-06$ & $4.14 \mathrm{E}-07$ & $8.29 \mathrm{E}-07$ & $4.14 \mathrm{E}-07$ \\
$\mathrm{~Pb}$ & $3.83 \mathrm{E}-07$ & $3.81 \mathrm{E}-07$ & $2.55 \mathrm{E}-07$ & $3.15 \mathrm{E}-07$ & $3.75 \mathrm{E}-07$ & $3.78 \mathrm{E}-07$ \\
\hline
\end{tabular}

In the present study, the concentration of only eight heavy metals were analyzed although many others metals persist in the environment. From the results of THQ and HI on the basis of these eight metals, it could be said that the studied fishes have no health hazard. Whereas there may be possibility of health hazard from the fishes considering all metals persist in the environment. Moreover, the TR values of $\mathrm{Cr}, \mathrm{Ni}$ and $\mathrm{Cd}$ of the studied fishes indicated that fishes had moderated and low cancer risk for those metals respectively. So continuous consumption of these fishes through diet over life time may cause serious health hazard to human.

\section{CONCLUSION}

The study was conducted to determine the concentrations of eight selected trace metals such as $\mathrm{Cr}, \mathrm{Mn}, \mathrm{Co}, \mathrm{Ni}, \mathrm{Cu}, \mathrm{Zn}, \mathrm{Cd}$, and $\mathrm{Pb}$ in three commonly consumed wild and cultured fish species from Meghna river and cultured pond of Madaripur district respectively. The seven metals except Co were detected in all studied fishes in various concentrations. Among all the studied fishes, wild species were observed more metals concentration than cultured one. The values of Hazard Index (HI) indicated the fishes are safe to eat but the continuous and excessive consumption with the significant amount of toxicants may be regarded 
a possible cancer risk to human in the lifetime considering the target cancer risk assessment of the study.

Acknowledgements: The authors are grateful to Jagannath University research grant and National Science and Technology Fellowship, Ministry of Science and Technology, Bangladesh for financial support. They are also grateful to Department of Zoology, Jagannath University, CARS (Centre for Advanced Research in Science), University of Dhaka, Bangladesh and BCSIR (Bangladesh Council of Scientific and Industrial Research), Dhaka for laboratory support.

\section{LITERATURE CITED}

AHMAD, M.K., ISLAM, S., RAHMAN, S., HAQUE, M.R and ISLAM, M.M. 2010. Heavy metals in water, sediment and some fishes of Buriganga River. Bangladesh. Int $J$ Environ Res. 4:321-332

AHMED, M.K., BAKI, M.A., KUNDU, G.K., ISLAM, M.S., ISLAM, M.M. and HOSSAIN, M. M. 2016. Human health risks from heavy metals in fish of Buriganga river, Bangladesh. Springer Plus 5:1697 DOI 10.1186/s40064-016-3357-0

AHSAN, M.A., SIDDIQUE, M.A.B., MUNNI, M.A., AKBOR, M.A., BITHI, U.H and MIA, M.Y. 2018. Analysis of major heavy metals in the available fish species of the Dhaleshwari River, Tangail, Bangladesh. Int. J. Fish. Aquat. Stud. 6(4): 349

AlAM L., MOKHTAR, M.B., AlAM, M.M., BARI, M.A., KATHIJOTES, N., TA, G.C. and ERN, L.K. 2015. Assessment of Environmental and Human Health Risk for Contamination of Heavy Metal in Tilapia Fish Collected from Langat Basin, Malaysia. Asian J. Water Environ. Pollut. 12 (2): $21-30$

AL-BUSAIDI, M., YeSUDHASON, P., AL-MUGHAIRI, S., AL-RAHBI, W. A. K., AL-HARTHY, K. S and AL-MAZROOEI, N.A. 2011. Toxic metals in commercial marine fish in Oman with reference to national and international standards. Chemosphere 85: 67-73.

AL-SABTI, K. and METCALFE, C.D. 1995. Fish micronuclei for assessing genotoxicity in water. Mutat Res. 343:121-135.

BAKI, M. A., SOJIB, M.F., SEHRIN, S., CHAKROBORTY, S., CHOUDHURY, T. R., BRISTY, M.S., AHMED, M. K., YUSOFF, S. B. and KHAN, M.F. 2019. Health risk assessment of heavy metal accumulation in the Buriganga and Turag River systems for Puntius ticto, Heteropneustes fossilis, and Channa punctatus. Environ Geochem Health. https://doi.org/10.1007/s10653019-00386-4

BASTA, N.T., RYAN, J.A. and CHANEY, R.L. 2005. Trace element chemistry in residual treated soil: key concepts and metal bioavailability. J. Environ. Qual. 34: 49-63.

BBS 2011. Household income and expenditure survey. Bangladesh Bureau of Statistics, Bangladesh CASTRO-GONZALEZ, M.I. and MENDEZ-ARMENTA, M. 2008. Heavy metals: implications associated to fish consumption. Environ Toxicol Pharmacol. 26:263-71. 
FAO 1983. Compilation of legal limits for hazardous substances in fish and fishery products. FAO Fish Circular 464:5-100. http://trove.nla.gov.au/version/22206109

FISHBASE. 2014 A global information system on fishes. http://www.fishbase.org/.

FRANK, A.P.C.G., JOHN, B.W., RONALD, W.R. and HAFFNER, G.D. 1999. Mechanism of Biomagnification in Fish under Laboratory and Field Conditions. Environ. Sci. Technol. 33(1): 133-141

GADO, M.S and MIDANY S.A. 2003. Studies on some heavy metal pollutants in cultured Oreochromis niloticus fish at Kafer EI-Sheikh Governorate. Kafer EI-Sheikh. J. Vet. Med. 1: 83-95

HASHIM, R., SONG, T.H., MD MUSLIM, N.Z. and YEN, T.P. 2104. Determination of Heavy Metal Levels in Fishes from the Lower Reach of the Kelantan River, Kelantan, Malaysia. Trop. Life Sci. 25(2): 21-39

HASSAN M., RAHMAN, M.A.T., SAHA, B. and KAMAL, A.K.I. 2015. Status of Heavy Metals in Water and Sediment of the Meghna River, Bangladesh. Am. J. Environ. Sci. 11 (6): 427-439.

HOSSAIN, M. A. R. 2014. An overview of fisheries sector of Bangladesh. Res. Agric. Livest. Fish. 1(1), 109e126. http://dx.doi.org/10.3329/ralf.v1i1.22375

ISLAM, M.S., AHMED, M.K. and AL-MAMUN, M.H. 2014. Heavy Metals in Cereals and Pulses: Health Implications in Bangladesh, dx.doi.org/10.1021/jf502486q | J. Agric. Food Chem.

JEZIERSKA, B. and WITESKA, M. 2006. The metal uptake and accumulation in fish living in polluted waters. Conference proceedings. Soil and Water Pollution Monitoring, Protection and Remediation. NAIV. 69

JOTHI, J.S., ANKA, I. Z., HASHEM, S. and MORSHED, S. 2018. Assessment of heavy metal concentration in edible fish muscle and water sample collected from different location in Chittagong: a public health concern. Ukr. Food J. 7(3)

KLOBUCAR, G. 2010. Genotoxicity monitoring of freshwater environments using caged carp (Cyprinus carpio). Ecotoxicol. 19(1): 77-84

LI, J., HUANG, Z., HU, Y. and YANG, H. 2013. Potential risk assessment of heavy metals by consuming shellfish collected from Xiamen, China. Environ. Sci. Pollut. Res. 20(5): 2937-47

LUCKEY, T.D. and VENUGOPAL, B. 1977. Metal Toxicity in Mammals. New York: Plenum Press. NRC.

MAHBOOB, S., AL-BALAWI, H.F.A., AL-MISNED, F., AL-QURAISHY, S. and AHMAD, Z. 2014. Tissue Metal Distribution and Risk Assessment for Important Fish Species from Saudi Arabia. Bull Environ Contam Toxicol. 92: 61-66

MALIK, N., BISWAS, A.K., QURESHI, T.A., BORANA, K. and VIRHA, R. 2010. Bioaccumulation of heavy metals in fish tissues of a freshwater lake of Bhopal. Environ. Monit. Assess. 167: $267-$ 176. 
MINISSI, S., CICCOTTI, E. and RIZZONI, M. 1996. Micronucleus test in erythrocytes of Barbus plebejus (Teleostei, Pisces) from two natural environments: a bioassay for the in situ detection of mutagens in freshwater. Mutat. Res. 367(4): p. 245-51

MITRAA, A., BANERJEEA, K. and SINHAA, S. 2011. Shrimp tissue quality in the lower Gangetic delta at the apex of Bay of Bengal. Toxicol Environ Chem. 93(3): 565-574

NYSDOH (New York State Department of Health), 2007. Hopewell precision area contamination: appendix C-NYS DOH. Procedure for evaluating potential health risks for contaminants of concern

OEHHA, 2011. Adoption of the revised air toxics hot spots program technical support document for cancer potency factor. [06/01/09] APPENDIX C UPDATED 2011

RAHMAN, A.K.A. 2005. Freshwater fishes of Bangladesh. 2 nd ed. Zoological Society of Bangladesh, Dhaka. pp-79, 130,133, 141, 176, 183, 203, 207, 305, 270-273285, 286, 333, 345, 346, $354,355,338$.

RAHMAN, M.S. and ISLAM, M.R. 2009. Effects of $\mathrm{pH}$ on isotherms modeling for $\mathrm{Cu}$ (II) ions adsorption using maple wood sawdust. Chem. Eng. J. 149: 273-280.

RAHMAN, M.S. and ISLAM, M.R. 2010. Adsorption of Cd (II) ions from synthetic wastewater using Maple sawdust. Energy Sources, Part A (Recovery, Utilization and Environmental Effect), 32:222-231

RAHMAN, M.S., MOLLA, A.H., SAHA, N. and RAHMAN, A. 2012. Study on heavy metals levels and its risk assessment in some edible fishes from Bangshi River, Savar, Dhaka, Bangladesh. Food chem. 134:1847-1854

ROY, S. P. 2010. "Overview of Heavy Metals and Aquatic Environment with Notes on Their Recovery." Eco scan: An International Quarterly J. environ. sci. 4: 235-240

SHAFI., M. AND QUDDUS., M.M.A. 1982. Bangladesher Matshya Shampad (in Bengali). 1 st ed. Bangla Academy, Dhaka. pp-2-14.

SHAMSUZZAMAN, M.M., ISLAM, M.M., TANIA, N.J., AL-MAMUN, M.A., BARMAN P.P. and XU, X. 2017. Fisheries resources of Bangladesh: Present status and future direction. J. Fish. Aquac. 2:145-156

TERRA, B.F., ARAUJO, F.G., CALZA, C.F., LOPES, R.T. and TEIXEIRA, T.P. 2008. Heavy metal in tissues of three fish species from different trophic levels in a tropical Brazilian river. Water Air Soil Pollut. 187:275-284

UJAH, I., OKEKE, D.O. and OKPASHI, V.E. 2017. Determination of Heavy Metals in Fish Tissues, Water and Sediment from the Onitsha Segment of the River Niger Anambra State Nigeria. $J$ Environ Anal Toxicol. 7(5) DOI: 10.4172/2161-0525.1000507

US Environmental Protection Agency (USEPA) 2012. Integrated Risk Information System of the US Environmental Protection Agency.

USEPA 2011. USEPA Regional Screening Level (RSL) Summary Table: November 2011 
USFDA 1993. Food and drug administration. Guidance document for nickel in shellfish. DHHS/PHS/FDA/CFSAN/Office of Seafood, Washington,

DC. http://www.cfsan.fda.gov/\%7Efrf/guid-as.html. Accessed March 17, 2016

VOSYLIENE, M.Z. and JANKAITE, A. 2006. "Effect of Heavy Metal Model Mixture on Rainbow Trout Biological Parameters.” Ekologija 4: 12-17

WHO (World Health Organization), 2010. Evaluation of the joint FAO/WHO Expert committee of food and additives (JECFA)

WHO 1989. Evaluation of certain food additives and the contaminants mercury, lead and cadmium, WHO Technical Report Series No. 505

WHO 1995. Environmental Health Criteria No 165: Inorganic Lead. Geneva (Switzerland): World Health Organization (WHO). http://www.inchem.org/documents/ehc/ehc/ehc165.htm.

(Manuscript received on 25 July 2021 revised on 30 September 2021) 